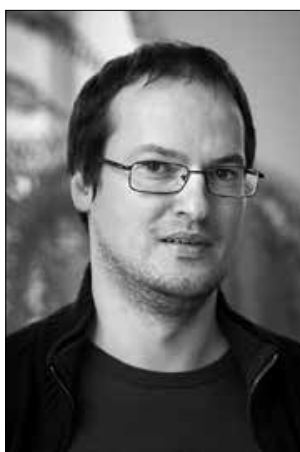

https://doi.org/10.24101/logos.2018.64

Gauta 20181018

\title{
EDVARDAS RIMKUS
}

Vilniaus Gedimino technikos universitetas, Lietuva

Vilnius Gediminas Technical University, Lithuania

\section{PATYRIMO SAMPRATOS: \\ I. KANTAS IR E. HUSSERLIS \\ Conceptions of Experience: \\ I. Kant and E. Husserl}

SUMMARY

The article investigates I. Kant's and E. Husserl's conceptions of experience and aims to find out the similarities and differences of these theories. One of the biggest transformations in the reception of kantian theory of experience is Husserl's interpretation of the thing-in-itself. Husserl rejects some very important aspects of this kantian concept; some meanings of this concept lose the importance in the context of Husserl's philosophy because of the very methodology of phenomenological philosophy: conceptions of transcendental reduction and relation between science and "lifeworld" show that Husserl's theory is orientated to everyday world and to introspectively grasped experience - these things are not apparent in Kant's theory, and kantian notion of the thing-in-itself is not needed for these conceptions.

\section{SANTRAUKA}

Straipsnyje analizuojamos I. Kanto ir E. Husserlio patyrimo sampratos - siekis aiškintis jų skirtumus ir panašumus motyvuoja šį tekstą. Straipsnyje keliamos hipotezės, jog viena didžiausių transformacijų, kurią padaro Husserlis, perimdamas kantiškąją patyrimo teoriją - tai "daikto savaime" sąvokos perinterpretavimas, atsisakant reikšmingų Kanto teorijoje jos aspektų; tam tikros šios sąvokos reikšmės Husserlio filosofijos kontekste praranda svarbą dèl pačios fenomenologinès filosofijos metodologijos: transcendentalinès redukcijos, taip pat huserliškoji "gyvenamojo pasaulio" ir jo santykio su moksliniu pažinimu sampratos rodo Husserlio filosofinès teorijos orientaciją j kasdienį ir introspektyviai suprantamą patyrimą, ko, viena vertus, kantiškojoje patyrimo teorijoje neaptiksime, o kita vertus, šioms sampratoms "daikto savaime" sąvoka yra nereikalinga. 


\section{IVADAS}

Patyrimo sąvoka ypač svarbi tampa Naujuju laikų filosofijoje. Pamatiniais filosofiniais principais oponuojančių viena kitai empirizmo ir racionalizmo stovykluc atstovai (pvz., Descartes'as ir Locke'as) savo filosofiniuose tyrinejjimuose pateikè skirtingas patyrimo sampratas ir nuo ju priklausomus ivvairių filosofiniu problemų sprendimus. Šiuolaikinès filosofijos srovèse - egzistencinèje, fenomenologinëje, analitinëje filosofijoje, taip pat pragmatizme ir tame, kas vadinama postmoderniąja filosofija, - pateikiami skirtingi patyrimo sąvokos aiškinimai.

I. Kanto transcendentalinè patyrimo samprata yra viena klasikiniu, nepraradusių aktualumo filosofinių teoriju - tai rodo iki šiol nesibaigiančios ivvairių filosofijos krypčių, srovių, pakraipų atstovų atožvalgos i ją. Šiame straipsnyje bandoma pateikti keletą preliminarių pastabu dèl I. Kanto ir E. Husserlio patyrimo teoriju santykio. Husserlio fenomenologinèje filosofijoje patyrimo sąvoka igauna ypač plačią prasmę. Kantas patyrimą suprato kaip empirini pažinima, o Husserlis jau kalba apie skirtingus patyrimo objektus ir tokius pat skirtingus ju patyrimo būdus. Kantiškoji ir huserliškoji fenomenologine patyrimo sampratos pasižymi tiek tam tikrais skirtumais, tiek panašumais - siekis juos aiškintis motyvuoja ši tekstą. Straipsnyje keliamos hipotezès, jog viena didžiausių transformaciju, kurią ivykdo Husserlis, perimdamas kantiškają patyrimo teorija - tai „daikto savaime" sąvokos perinterpretavimas atsisakant reikšmingu Kanto teorijai jos aspektų; tam tikros šios sąvokos reikšmès
Husserlio filosofijos kontekste praranda svarbą dèl pačios fenomenologinès filosofijos metodologijos: transcendentalinès redukcijos, taip pat huserliškoji „gyvenamojo pasaulio" ir jo santykio su moksliniu pažinimu sampratos rodo Husserlio filosofinès teorijos orientaciją i kasdieni ir introspektyviai suprantamą patyrima, ko, viena vertus, kantiškojoje patyrimo teorijoje neaptiksime, o kita vertus, šioms sampratoms kantiškoji „,daikto savaime“ sąvoka yra nereikalinga.

Kantiškoji patyrimo sąvoka (Erfahrung) yra susipynusi su daugybe fundamentalių Kanto teorinèje filosofijoje nagrinëjamų temų: metafizikos kaip mokslo pagrindimo klausimu, transcendentinès metafizikos kritika, teorinio ir praktinio proto sampratomis, senojoje spekuliatyviojoje metafizikoje ir matematiniame eksperimentiniame gamtos moksle prieinamu pažinimo ribų supratimu, apriorinių sintetinių sprendinių galimybès klausimu ir kt. Kantui patyrimas - tai empirinis pažinimas, arba matematinio eksperimentinio gamtos mokslo pažinimo rezultatai - šių mokslų metodais nustatyti faktai apie pažinimo objektus (teiginiai apie ju savybes bei ivvairius tarpusavio santykius). Kantiškojoje patyrimo teorijoje aiškinamas ir pats patyrimo procesas, kuris suprantamas kaip sintezés procesas: juslinè medžiaga (išorinès sąmonès atžvilgiu realybės generuojami jusliniai vaizdiniai (sinnliche Vorstellungen)) yra sujungiama su konceptualiaisiais vaizdiniais, arba sąvokinėmis formomis. Kanto patyrimo teorijoje jusliniai vaizdiniai ir sąvokos ne tik atskiriami vieni nuo kitų, 
bet netgi radikaliai išgryninami (žr., pvz., Kant 1996: 55). Grynuosius juslinius potyrius patyrimą išreiškiančiuose teiginiuose sustruktūrina ir išreiškia sąvokos, arba sąvokinès formos, kurias Kantas vadina apriorinemis patyrimo formomis ir išskiria tris jų rūšis: juslumo (erdvė ir laikas), mąstymo (kategorijos), schemas (bendrąsias / abstrakčias sąvokas, kurios skirtos empiriniams ir matematiniams objektams ivardinti). Apriorines patyrimo formas Kantas supranta kaip sąmonés įnešamus i patyrimą konceptualiuosius vaizdinius, jie, Kanto požiūriu, nèra išvedami iš patyrimo objektų, bet yra patyrimo kaip empirinio pažinimo sąlygos. Šie ba- ziniai konceptualieji patyrimą grindžiantys elemantai taip pat yra pagrindas apriorinių sintetinių sprendinių, anot Kanto, aptinkamų tiek gamtos moksle, tiek matematikoje. Pažinimą kaip sintezès procesą vykdo transcendentaliné samone, arba kantiškai - transcendentalinè apercepcija ${ }^{1}$. Patyrimo, arba empirinio pažinimo, medžiagos ir formos atskyrimas yra kitos fundamentalios kantiškosios dichotomijos tarp daikto savaime (Ding an sich) ir reiškinio (Ercheinung) teorinis pagrindas. Pastaraja skirtimi Kantas mąsto pažinimo ribas, kurias, jo požiūriu, prieina spekuliatyvioji metafizika ir matematinis eksperimentinis gamtos mokslas.

\section{E. HUSSERLIO ATOŽVALGA ! KANTIŠKAJA PATYRIMO TEORIJĄ}

Edmundas Husserlis (1859-1938) Kanta, kaip ir R. Descartes'ą bei F. Brentano, ivardijo kaip fenomenologinès filosofijos pradininką. Revoliucinis filosofijoje Kanto transcendentalinis metodas, Husserlio įsitikinimu, yra visiškai išplètojamas jo paties transcendentalinèje fenomenologijoje $\mathrm{e}^{2}$. Husserlis savo filosofinę poziciją vadina transcendentaliniu idealizmu ${ }^{3}$, kuris yra artimas, tačiau tik kai kuriais aspektais, Kanto transcendentalinio idealizmo versijai.

Husserlis supranta, kad jo fenomenologijoje pritaikyta sąvoka transcendentalinis yra nutolusi nuo Kanto filosofijos pagrindinių prielaidu, problemų ir metodų. Tačiau šis pritaikymas remiasi issitikinimu, jog Kanto ir jo sekejjų nagrinètos problemos gali būti perorientuotos i fenomenologinę filosofiją ir sprendžiamos fenomenologiniu metodu. Husserlio požiūriu, net ir oponuojant Kantui bei pokantinių filosofijos mokyklų metodams ir atmetant bandymus pratęsti ir / ar pagerinti Kanto filosofija, čia galima ižvelgti artimą fenomenologijai filosofinį principą - tikros mokslinès filosofijos pagrindas yra samonés aprašymas; samo$n \dot{e}$ yra tam tikras pamatas kalbant tiek apie pažinima, tiek apie praktini žmogaus veikimą pasaulyje. Kantas Husserliui atrodo transcendentalinès sąmonès teorijos arba transcendentalinio subjektyvumo sampratos filosofijoje kūrèjas (Husserl [1924] 1974: 9-10, 13).

Pasak Husserlio, svarbiausia yra tai, kad Kantas pateikè pačią transcendentalinès filosofijos idejja, kuri išreiškiama ir kopernikiškosios revoliucijos sąvoka. Husserliui Descartes'as yra transcendentalinès filosofijos pirmtakas ${ }^{4}$ - jo meditacijos sukūrè moderniąą filosofiją. Nuo Descartes'o laikų savyje uždaras subjektyvumas, akivaizdžiai fiksuojamas kaip 
grynasis sąmonès gyvenimas, prieinamas savirefleksijos būdu, yra gerai žinomas dalykas. Ego cogito, Husserlio požiūriu, gali būti vertinama kaip pirmoji transcendentalinio subjektyvumo forma; transcendentalinès dvasios yra Hume'o tyrinėjimai, pažadinę Kantą iš dogmatiško snaudulio; artimi transcendentalinei filosofijai taip pat yra Leibnizo ir Berkeley'o tyrinejjimai (Husserl [1924] 1974: 17-18, 29, 49). Anot Husserlio, Descartes'o mąstymui pritrūko radikalumo: savo teoriniuose ieškojimuose jis nepajègè atsikratyti prietaro - geometrijos ir apskritai matematinio gamtamokslio kaip mokslo idealo vertinimo. Husserlis kvestionuoja Descartes'o argumentacija, kuri apeliuoja i tam tikrą normatyviai nusakomą mokslo idealą ir i ígimtas bei akivaizdžias idejjas.

Descartes'as laikè iš anksto savaime suprantamu dalyku tai, kad universalus mokslas privalo turèti dedukcinès sistemos pavidala, t. y. sistemos, kurioje visa konstrukcija turi remtis dedukciją grindžiančiu aksiominiu pamatu. Anot Descartes'o, panašų i geometrijos aksiomų vaidmeni universaliajame moksle turi atlikti ego absoliutaus savi-tikrumo aksioma kartu su šiam ego igimtais aksiominiais principais, tik tiek, kad toks aksiominis pagrindas yra gilesnis negu geometrijos ir reikalingas tam, kad galètų dalyvauti ir pastarosios absoliučiame pagrindime (Husserl [1931] 2005: 13-14).

Husserliui fenomenologija - tai sąmonès filosofija. Samone čia reiškia ne psichinę būseną ar buvimą sąmoningam (kieno priešingybè būtų buvimas be sąmonès ar kokia nors ikisąmoninè būklè kuo pasižymi negyvi daiktai arba žemesnio nei žmogaus sąmoningumo būtybès), bet intencionalu patyrima (Holzhey 2010: 29). Fenomenologinè sąmonè yra intencionalus santykis su patiriamu fenomenu. Transcendentalinis subjektyvumas reiškiasi kaip įvairūs intencionalūs santykiai su patyrimo objektais. Svarbiausias Husserlio filosofijoje yra fenomenologinès redukcijos metodas. Husserlio požiūriu, egzistuoja fundamentalus skirtumas tarp natūralios ir transcendentalinès refleksijos, tarp natūralios nuostatos ir to pasaulio suvokimo, kuris pasiekiamas per fenomenologinę redukciją. Natūralioje nuostatoje skleidžiasi žmogaus gyvenimas kaip praktinis veikimas pasaulyje. Šitokia nuostata būdinga visiems istoriniams žmonijos laikmečiams. Natūralios nuostatos yra persmelktas kasdienis žmogaus gyvenimas (Husserl [1924] 1974: 20). Kaip nurodo P. Gorneris, neabejojanti issitikinimą realia pasaulio kaip visumos egzistencija Husserlis vadina pamatine teze arba natūraliąja nuostata, kurioje sąmoné nukreipta i pasaulio objektus, - tai yra sąmonès intencionalumas. Natūralioje nuostatoje suvokiame save pačius ir kitus asmenis kaip priklausančius vienai erdvinei-laikinei realybei, kuri yra tam tikra duotybè. Aš esu sąmonès subjektas, taip pat psichofizinè būtybė pasaulyje, susijusi priežastiniais ir kitokiais ryšiais su ìvairiais dalykais pasaulyje. Fenomenologinè arba transcendentalinè redukcija ineša radikalú pokyti pamatinèje tezèje arba natūralioje nuostatoje. Transcendentalinè redukcija transformuoja natūraliąją nuostatą ir pamatinę tezę, bet ne i jai priešingą arba antitezę. Po transcendentalinès redukcijos tampa nebesvarbus pats objektų egzistencinis statusas. Vyk- 
doma epoché - natūralios nuostatos suskliaudimas, arba sulaikymas. Šio įsitikinimo ir nuostatos sustabdymas leidžia nukreipti mūsų dèmesį nuo daiktų pasaulyje bei pasaulio paties savaime ir sutelkti dèmesị i pasaulio daiktu sąmonę, i patiriamą pasauli kaip visumą. Pasaulis neišnyksta, mes tiesiog pradedame domètis nebe tokiu pasauliu, koks jis yra savaime, o tokiu pasauliu ir jo dalykais, kurie reiškiasi mums kaip sąmonès objektai arba intencionalūs objektai, vadinami fenomenais. Husserlis fenomenologiją supranta kaip aprašymą pamatinių sąmonès struktūrų ir pačių ìvairiausių sąmonès objektų arba transcendentalinio patyrimo objektų. Sąmonè, kuri pasiekiama per fenomenologinę redukcija, yra transcendentalinė sąmonè. Vèlesnès Husserlio fenomenologijos versijos apeliuoja i tai, kas vadinama "gyvenamuoju pasauliu" (Lebenswelt) ${ }^{5}$. Tai yra pasaulis, kuriame gyvename, pasaulis toks, koki ji ir kaip patiriame. Tai tam tikras pasaulio patyrimo sluoksnis, pasaulis, kuri mes patiriame kasdieniame ikimoksliniame arba nemoksliniame gyvenime. Gyvenamasis pasaulis yra percepcijos pasaulis ir jis yra mokslinio pasaulio pagrindas. Mokslas tiria daiktus taip, kaip jie objektyviai yra, nepriklausomai nuo subjektyvumo. Subjektyvus gyvenamasis pasaulis, manoma, yra tai, kas turi būti įveikta mokslo ir mokslinio pasaulèvaizdžio, bet tai, Husserlio požiūriu, yra klaidingas požiūris. Mokslas tėra istoriškai vẻlyva praktikos forma, kuri iškyla gyvenamajame pasaulyje ir galiausiai yra suprantamas tik šiame gyvenamojo pasaulio kontekste (Gorner 2006: 501-502). Su Gornerio pozicija yra suderinami ir D. Follesdalio pateikiami Husserlio "gyvenamojo pasaulio" sąvokos komentarai: gyvenamasis pasaulis turi intersubjektyvumo ir komunikatyvumo dimensijas; gyvenamasis pasaulis yra vienas, nors jis gali būti patiriamas bei suprantamas įvairių žmonių skirtingai; gyvenamasis pasaulis nèra opozicija moksliniam pasaulèvaizdžiui ar moksliniam pasaulio patyrimo būdui - mokslas yra gyvenamojo pasaulio dalis ir kitaip glaudžiai sąveikauja su gyvenamuoju pasauliu (žr.: Follesdal 2000). Natūralioje refleksijoje sąmone suprantama kaip realus „žemiškas“ arba kasdienis reiškinys, susipynęs su gamta, o grynoji refleksija suranda grynajją transcendentalinę sąmonę. Transcendentalinis patyrimas prieina ivairius sąmonès sluoksnius ir patyrimo rūšis: teorinį patyrimą ir teorinę sąmonę, faktinį-mokslinį patyrima, eidetinę sąmonę ir kt. ${ }^{6}$ (Husserl [1924] 1974: 35, 39).

Husserlio požiūriu, Kantas pirmasis sukūrẻ mokslinę transcendentalinès filosofijos sistema, kuri buvo nebe „dogmatine“", bet "kritiné" metafizika. Kantas tyrè mokslus transcendentaliniu aspektu, atskleisdamas sąmonès struktūras, pagrindžiančias pačią mokslinio pažinimo galimybę. Matematiniai gamtos mokslai yra steigiami transcendentalinio subjektyvumo. Kantas ịvykdè revoliuciją filosofijoje įvedęs i ją naują metodologiją: transcendentalinis subjektyvumas yra tas laukas, kuriame atsiranda visi metodai. Kanto revoliucija filosofijoje yra ne tik istorinis faktas, bet taip pat vis dar netobula aktualizacija tos filosofijos, kuri pereina nuo natūralios prie transcendentalinès nuostatos, nuo naivaus, pozityvaus arba dogmatinio, prie transcen- 
dentalinio pažinimo - pasaulio pažinimo per transcendentalinę savimonę. Husserlio požiūriu, nèra būtina priimti Kanto sistemą tokia, kokia ji yra arba patobulinti jos dalis, daug svarbiau suprasti jo ivykdytos revoliucijos prasmę ir tai, kad jis buvo pionierius, bet ne tas, kuris pateikè išbaigtą transcendentalinę filosofiją (Husserl [1924] 1974: 50-55; Husserl [1931] 2005: 188-194).

\section{BAIGIAMOSIOS PASTABOS IR IŠVADOS}

Huserliškoji transcendentalinė sąmonė yra intencionalus santykis su patyrimo objektu. Husserlis savo fenomenologiją supranta kaip universalią patyrimo teoriją (Husserl [1924] 1974: 30-31). Žvelgiant iš Husserlio filosofijos perspektyvos, kantiškasis patyrimas arba empirinis reiškinių santykių pažinimas apimtų tik fenomenologiškai suprantamą mokslinị-faktini pažinimą, kitu patyrimo sluoksnių ir huserliškai suprantamu transcendentalinès sąmonès aspektu Kanto teorija iš tikro neapima. Netgi kantiškai suprantamas vidinis patyrimas yra visiškai priklausomas nuo Kanto pateiktos išorinio patyrimo, orientuoto i empirini pažinima, sampratos (žr., pvz., Emundts 2010: 168-172). Vidinès žmogaus būsenos yra tam tikri vaizdiniai, kurie yra sukeliami, arba priežastingai sąlygojami "daikto paties savaime", kuris koreliuoja su anapus sąmonès esančia, arba nuo sąmonès nepriklausoma, išorine realybe. Kantiškieji suvokimo sprendiniai $^{7}$ taip pat neišsemia fenomenologiškai suprantamos transcendentalinio subjektyvumo įvairovès. Kantiškoji patyrimo samprata, palyginti su fenomenologine, atrodo gana siaura, tačiau tai suprantama turint omenyje, kokias skirtingas problemas sprendžia Kantas ir Husserlis. Kantas pirmiausia kritikavo spekuliatyviają metafizika, kvestionavo jos moksliškuma, jos kaip transempirinių esiniu pažinimą teikiančios instancijos statusą. Husserli domina pats transcendentalinis subjektyvumas ir transcendentalinè sąmonè. Žvelgiant iš fenomenologinès perspektyvos galima teigti, kad Husserlis išplečia Kanto transcendentalini metodą ir dèl to pačią patyrimo sąvoką, tačiau, gretinant filosofu teorines sistemas, skirtumu ir nesuderinamumu galima pamatyti ne mažiau, nei panašumų

Husserlio požiūriu, reikia atsisakyti blogaja prasme „metafiziniu“" kantiškosios proto kritikos elementu - „daikto paties savaime" doktrinos, transcendentalinès apercepcijos arba „sąmonès apskritai" mitologijos ir kt., kurie yra svetimi fenomenologiniam transcendentalizmui. Kantiškąją apriori koncepciją Husserlis vadina "pusiau mitine", ir ją reikia pakeisti aiškesne fenomenologine "esmès" koncepcija, tai, jo požiūriu, dar Hume'as turëjo galvoje kalbėdamas apie idèjų santykius - ką jis interpretavo sensualistiškai ir nominalistiškai, tokiu būdu visa tai nuvertindamas (Husserl [1924] 1974: 13-14). Tad Husserlis atsisako ir / arba savaip perinterpretuoja pamatinius kantiškosios patyrimo teorijos komponentus, dèl ko jo transcendentalinio idealizmo versijoje išryškejja teoriniai savitumai, kurių Kanto filosofijoje arba visai neaptiksime, arba jiems yra suteikiama kiek kitokia prasmè. 
Husserlis kritikavo Kanto teorijas, bet taip pat save matè kaip kantiškosios filosofijos ippedinį ir netgi išplètotoją. Tačiau dèl to, kad Husserlis atsisako pamatiniu Kanto teorinės filosofijos sąvoku, tokių kaip daiktas savaime ir kt., pasidaro sunku tokì požiūri priimti.

Husserlis neprièmè kantiškojo „daikto paties savaime" problemos supratimo. Kaip nurodo H. Philipse'as, pagal Husserlio percepcijos teorija, daiktas savaime kantiškaja prasme paprasčiausiai nėra duotas sąmonei. Nèra jokių apibrèžtų požymių, proto ar sąmonés aktų, nurodančių i daiktą savaime, tad jis yra anapus fenomenologinès epistemologijos. Galima būtų manyti, kad tokiu būdu Husserlis išvengė daikto savaime klausimo sprendimo savo filosofijoje, tačiau ši išvada nèra teisinga. Matomi du daikto savaime klausimo supratimo etapai jo filosofijoje. Husserlis, kaip ir Hume'as, atmetè visas sąvokas, kurių vartojimo negalima pagristi patyrimu. Postuluoti daiktus savaime absurdiška, nes jų negalima patirti iš principo, jų negalima nurodyti aktualioje arba tiesiogineje patirtyje. Vèliau Husserlis pateikè kitoki požiūrị: mes galime suvokti daiktą savaime, jeigu fenomeną suvokiame visiškai ir adekvačiai ${ }^{9}$. Tad daiktas savaime pasirodo kaip ideali fenomenalaus daikto suvokimo riba. Šiuo požiūriu visiškai suprastas fenomenas ir yra daiktas savaime. Šią savo sampratą Husserlis pritaiko pasaulio suvokimui: pasaulis savaime yra intencionalus koreliatas idealios mokslininkų bendruomenès, apimančios visą mokslą. $\mathrm{O}$ šitokia daikto savaime samprata stipriai skiriasi nuo tradicinès - tai pripažino ir pats Husser- lis (Philipse 1995: 271-275). Net ir prièmus toki požiūrị i daiktą savaime, neatrodo, kad Husserlio filosofijai kenktu kantiškoji daikto savaime samprata ir kad šiuo klausimu nèra įmanoma Kanto ir Husserlio teoriju suderinti. Gal toks derinimas negriautų fenomenologinès filosofijos projekto, o kaip tik suteiktu Husserlio fenomenalizmui gilesni teorini pagrindą.

Kanto patyrimo teorija yra epistemologinè, susitelkianti ì mokslinio pažinimo analizę ir tokio pažinimo legitimaciją transcendentinès, arba tradicinès spekuliatyviosios, metafizikos atžvilgiu. Būtent tuo tikslu Kantas nagrinėja sąmonès struktūras (apriorines sąvokas ir teorinius principus) kaip patyrimo, arba empirinio pažinimo, galimybės sąlygas. Pažinimo galimybès sąlygų teorijos Husserlis nepateikia. Gyvenamojo pasaulio ir jo santykio su mokslu samprata yra huserliška, ir tai yra svetimi Kanto transcendentalizmui dalykai.

Tiek, kiek fenomenologinè refleksija yra introspektyvaus patyrimo atmaina, tiek ji nutolsta nuo kantiškosios patyrimo sampratos - ne tik dèI to, kad Kantas introspektyviu patyrimu nesidomėjo tiek ir taip kaip Husserlis, bet ir dèl to, kad introspekcija kaip tyrimo metodas suponuoja kiek kitoki, daugiau substancializuota, sąmonès supratima, kas nebūdinga kantiškajai sąmonès teorijai. Husserlio transcendentaliné filosofijos koncepcija yra dekartiška, dekartiškas ir jo sąmonès supratimas.

Husserlio apriori koncepcija yra kitokia nei Kanto. Kanto sintetiniams a priori sprendiniams būdingi būtinumas ir visuotinumas. Sintetiniai aprioriniai prin- 
cipai yra patyrimo galimybės sąlygos, todèl jie yra transcendentaliniai. Husserlis taip pat vartoja sintetiniu a priori sprendinių sąvoką ${ }^{10}$, bet jo koncepcija itraukia svetimą Kantui esmių intuicija, arba esmėžiūrą. Husserlio požiūriu, ne tik atskirybès, bet ir sąvokos arba bendrybès gali būti patiriamos kaip tam tikri stebiniai. Kiekviena atskirybė turi esmę arba idejąa. Kiekvienas atskiras garsas turi universalią esmę garso kaip tokio. Tad egzistuoja ne tik juslinè, bet ir eidetine arba idèjinè intuicija, idejja kaip stebinys

\section{Literatūra}

Emundts D. 2010. The Refutation of Idealism and the Distinction between Phenomena and Noumena. The Cambridge companion to Kant's Critique of pure reason. Ed. P. Guyer. Cambridge: Cambridge University Press.

Follesdal, D., 2000. Lebenswelt Husserlio tekstuose. Žmogus ir žodis IV: 56-66.

Gorner, P. 2006. Phenomenological Interpretations of Kant in Husserl and Heidegger. A Companion to Kant. Edited by Graham Bird. Oxford: Blackwell Publishing.

Husserl, E. [1924] 1974. Kant and the Idea of Transcendental Philosophy. Translated by T. E. Klein and W. E. Pohl. The Southwestern Journal of Philosophy. Volume 5 (1974): 9-56.

Husserl, E. [1931] 2005. Karteziškosios meditacijos. Vertè T. Sodeika. Aidai: Vilnius.

Holzhey H. 2010. Neo-Kantianism and Phenomenology: The Problem of Intuition. Neo-kantianism in contemporary philosophy. Edited by R. A. Makkrell and S. Luft. Bloomington and Indianapolis: Indiana university press.

Kant, I. 1996 [1787]. Grynojo proto kritika. Vertè R. Plečkaitis. Vilnius: Mintis.

Kantas, I. 1972 [1783]. Prolegomenai kiekvienai metafizikai, galèsiančiai būti mokslu. Vertè R. Plečkaitis. Vilnius: Mintis.

Luft, S. 2007. From Being to Givenness and Back: Some Remarks on the Meaning of Transcendental Idealism in Kant and Husserl. International Journal of Philosophical Studies, Vol. 15, No. 3: 367-394.
(Gorner 2006: 504-505). Intelektualini stebèjimą arba intelektualinę intuiciją Kantas atmeta, jo požiūriu, sąvokos tèra tam tikros mąstymo formos, kuriomis sutvarkoma pojūtinio patyrimo medžiaga arba jusliu teikiami duomenys. Bendrosios sąvokos (kas yra ir platoniško tipo idejos) Kanto patyrimo teorijoje yra perinterpretuotos kaip schemos - apriorinio pažinimo aparato dalys. Jos nesuponuoja Kanto esencializmo ar metafizinio realizmo, bet rodo nominalistinę Kanto patyrimo teorijos orientacija.

Mickūnas, A., Steward, D. 1994. Fenomenologine filosofija. Vilnius: Baltos lankos.

Mickūnas, A. 1998. Transcendentalinès sąmonès pro-simboliai. Sociologija. Mintis ir veiksmas 1 : 21-30.

Philipse, H. 1995. Transcendental idealism. The Cambridge Companion to Husserl. Ed. by B. Smith and D. W. Smith. Cambridge: Cambridge university press.

Planting, Th., 1972. The Real Meaning of Kant. In URL: http://plantinga.ca/p/YAM.HTM\# [žiūrèta 201804 11].

Rimkus E. 2012. Kantiškoji „daikto paties savaime“ problema Rae Langton interpretacijoje, Problemos 81: 144-156.

Rimkus, E. 2013. Kantiškoji patyrimo samprata ir pažinimo ribų problema, Problemos 83: 35-48.

Rimkus, E. 2014. Kantiškoji patyrimo samprata ir jos recepcija. Daktaro disertacija. Vilniaus universitetas.

Rimkus, E. 2015. I. Kanto patyrimo teorijos metafizinè komunikacija. Santalka: filosofija, komunikacija 21: 73-85.

Rimkus, E. 2017. Some remarks on the criticism of Kant's theoretical philosophy in the Vilnius Epistemological School. Studia Philosophica Kantiana. Prešov: Inštitút filozofie Filozofická fakulta PU v Prešove., iss. 2, p. 3-19.

Tengelyi, L. 2005. Experience and infinity in Kant and Husserl. Tijdschrifi voor Filosofie 68: 479500 . 


\section{Nuorodos}

${ }^{1}$ Šios ir kitų Kanto teorinès filosofijos sąvokų istorinè recepcija yra komplikuota ir kontroversiška. Šiame straipsnyje nesiekiama nei išsamiai aiškinti šias sąvokas, nei rekonstruoti kantiškąsias teorijas, kurių kontekste jos turètu būti suprantamos, nes tai netilptu i šio straipsnio rèmus. Kanto patyrimo teorija ir jos inspiruojamos teorinès diskusijos yra nagrinètos kituose autoriaus straipsniuose, tad čia nebesikartojama, žr.: Rimkus 2012, 2013, 2014, 2015, 2017.

2 Pasak P. Gornerio, būtent remiantis šitokiu požiūriu kritikuojama Kanto filosofija, fenomenologiją suprantant kaip galutini atsakymą i pagrindini epistemologijos klausimą: kaip yra galimas pažinimas? (Gorner 2006: 500).

3 Pvz., žr. Husserl [1931] 2005: 107. Transcendentalinis idealizmas yra brandžioji Husserlio filosofine pozicija, ginama veikaluose: Formalioji ir transcendentaline logika (1929), Karteziškosios meditacijos (1931), Europietiškuju mokslu krizé (1954) ir kt. (Philipse 1995: 240). Dauguma vèlyvujuu Husserlio darbu yra diskusija su Kantu ir mèginimas suformuluoti savo paties filosofinę poziciją Kanto ir neokantininkų filosofijos atžvilgiu; žr., pvz., Planting 1972.

4 Transcendentalinio ego koncepciją Husserlis supranta kaip metodologinę visų mokslų, taip pat ir filosofijos, pagrindo teoriją ir kildina ją iš Descartes'o ego cogito sampratos. Kaip ir prancūzu mąstytojui, taip ir fenomenologijos kūrejui pirmiausia rūpejjo autentiškai pagrịsti mokslus ir svarbiausiaji iš ju - universalujị filosofijos mokslą. Tačiau Husserlis nesitenkino, nors, jo manymu, strategiškai ir teisinga, bet galiausiai prie klaidingų išvadų atvedusia Descartes'o teorija. Husserlio požiūriu, Descartes'o subjektas išlieka tam tikras esinys pasaulyje, o Kanto svarba yra ta, kad jis konvertavo Descartes'o subjektyvizmą i transcendentalinę filosofiją (Gorner 2006: 503). Transcendentalinis subjektyvumas jau išreiškia objektyvaus mokslinio pažinimo galimybès sąlygas, tad jis yra kitoks nei dekartiškasis subjektyvumas, dogmatiškai visą pasaulį dedukuojantis iš ego centro. Kanto subjektas yra transcendentalinis, nes jame arba per ji steigiamas pasaulis kaip mokslinio pažinimo objektas.

${ }^{5}$ P. Gorneris nurodo, jog kaip tik gyvenamasis pasaulis yra ta terpè, kurioje iškyla mokslo klausimai, ir mokslininkas visada turi apeliuoti $\mathfrak{i}$ gyvenamąji pasauli atsakydamas i tokius klausimus ir tikrindamas atsakymus i juos. Fizikai mato savo instrumentus gyvenamajame pasaulyje, ir tai, ką jie mato per juos, yra gyvenamojo pasaulio objektai. Gyvenamasis pasaulis yra mokslo pagrindas. Husserlis kalba apie Galileo Galilei įvykdytą gamtos matematizavimą. Ikimoksliniame pasaulio patyrime pasaulis yra suvokiamas subjektyviai. Galileo sumanè įveikti subjektyvumą ir reliatyvumą taikydamas geometriją ir matematiką - erdvės ir laiko formas gamtai. Per idealizuotas formas objektyviai pažistamas pasaulis, jo reiškiniai, kurie nèra nei tikslūs, nei aiškūs gyvenamojo pasaulio dalykai. Tokios idealizacijos, pvz., yra matematinis taškas, tiesė, priežastingumo kategorija ir kt. Objektyvus mokslinis pasaulis yra sukonstruojamas per šitokias mokslines idealizuotas sąvokas ir principus, kurie patys kyla iš gyvenamojo pasaulio. Tad gyvenamojo pasaulio ir mokslinio pasaulio priešinimas Husserlio filosofijos kontekste yra absurdiškas. Gyvenamasis pasaulis yra steigiamas transcendentalinio subjektyvumo (Gorner 2006: 502-503).

${ }^{6}$ Husserlis kalba apie transcendentalinę filosofiją kaip apie moksla, kuris tyrinejja grynajji subjektyvumą apskritai ir visas galimas jo pasireiškimo formas (Husserl [1924] 1974: 30). Fenomenologineje filosofijos tradicijoje patyrimo sąvoka igauna plačią reikšmę: kalbama ne tik apie skirtingus arba skirtingai egzistuojančius fenomenus, bet ir skirtingus ju patyrimo būdus vienaip yra patiriami fiziniai daiktai, kitaip matematiniai objektai, emocijos, vertybès ir kt. (Mickūnas, Stewart 1994: 42). Teigiama, kad fenomeno patyrime esmingai dalyvauja kalba. Ivairūs kalbos vartojimo būdai sukuria skirtingus fenomenu patyrimo būdus: „, $<. .>$ teorinè kalba perima teorini patyrima, kuris skiriasi nuo estetinès kalbos ir jos patyrimo, kaip ir empirinè kalba perima empirini patyrimą; lygiai taip pat pačios kalbos patyrimas skiriasi nuo kitokio pobūdžio patyrimo. $<\ldots>$ suformuluotume visiškai metafizišką ir dogmatišką teiginį, jeigu tartume, kad yra tik vienas patyrimo būdas, o tuo tarpu visi kiti būdai subjektyvūs. Čia paaiškèja, kad yra pateikiamas subjektyvumo patyrimas, kuris yra objektyvus" (Mickūnas 1998: 22; taip pat žr.: Husserl [1924] 1974: 30-31). 
7 Prolegomenuose Kantas aptaria skirtumą tarp suvokimo sprendiniu (Wahrnehmungsurteil) ir patyrimo sprendiniu (Erfahrungsurteil). Suvokimo sprendiniais išreiškiama tai, ką žmogus patiria tiesiogiai juslinio patyrimo prasme ir ką jis sąvokomis įvardija kaip paprastus, akivaizdžius reiškinius. Patyrimo sprendiniais jau išreiškiami objektyvūs moksliniai faktai, šiais sprendiniais fiksuojami intersusbjektyviai verifikuojami, arba moksliniais metodais patvirtinami, faktiniai teiginiai apie patiriamų objektų savybes ir įvairius jų santykius (Kantas 1972: 84-85). Patyrimo sprendiniams formuluoti panaudojamos apriorinès sąvokos bei principai (pvz.: priežastingumas, erdvė, laikas ir kt.). Atrodo, Kanto patyrimo sprendinius galima interpretuoti ir kaip hipotezes, kurias dar reikia patvirtinti empiriniu tyrimu: stebejjimais ir/ar eksperimentais.

${ }^{8}$ Husserlio transcendentalinis idealizmas nèra pasaulio interpretacija, jis kaip tik pašalina toki interpretavimą tam, kad būtų galima sąmoningai reflektuoti pasaulio interpretacijas (Philipse 1995: 251). Transcendentalinè fenomenologija teikia metodines priemones, kuriomis galima rekonstruoti ivairius pasaulio patyrimus ir jo supratimus. Transcendentalinè redukcija neišreiškia ontologinio požiūrio i̇ tikrovę, kaip jo neišreiškia ir Kanto kritinis arba transcendentalinis idealizmas. Šiuo požiūriu, Kanto ir Husserlio filosofiniai projektai atrodo gana artimi.

${ }^{9}$ Husserlis, kitaip negu Kantas, teoretizuoja santyki tarp daikto savaime ir reiškinio. Reiškinys
Husserliui yra daikto savaime profilis, aspektas arba daikto patyrimas iš tam tikros jo perspektyvos. Pažinti reiškini - tai suprasti daiktą savaime tik iš vienos, arba iš specifinès perspektyvos (Tengelyi 2005: 488). Taip daiktas savaime Husserlio filosofijoje tampa ne iš principo žmogiškam pažinimui neperprantamu objektu, bet tam tikra idejja - objekto, kuris yra pažintas visais galimais aspektais, kai yra pažinti visi galimi jo reiškiniai (taip pat žr. Luft 2007). Tačiau tai jau yra ryški kantiškosios daikto savaime idejjos transformacija. Kantas daiktą savaime nusako kaip reiškinio priežasti. Ši tezė Husserliui neatrodo priimtina. Huserliškai suprantamas daiktas savaime tampa tik reguliatyvia idèja, nusakančia daikto galimų pažinti aspektu potencialią begalybę. Husserlio įsitikinimu, transcendentalinė filosofija negali atvaizduoti "daiktu pačiu savaime“, nes jie negali būti pateikti arba duoti sąmonei. Pasak P. Gornerio, Husserlio fenomenologijos pagrinduose yra griežta koreliacija tarp būties (Sein) ir sąmonès (Bewusstsein). Intencionalaus sąmonès ir objekto santykio atžvilgiu nepažinaus daikto savaime idèja neturi jokios prasmès. (Gorner 2006: 504).

${ }^{10}$ Huserliško sintetinio a priori sprendinio pavyzdys: tas pats paviršius negali būti vienu metu ir raudonas, ir žalias. Tokie sprendiniai yra būtinos tiesos, bet jos negali būti konvertuojamos $i$ analitines tiesas. Sintetiniu materialiu tiesu negalima redukuoti $\mathfrak{i}$ formalias logines tiesas (žr. Gorner 2006: 504-505). 